\title{
Optimization of gelatinolytic enzyme production by B. amyloliquefaciens sp. H11 through Plackett-Burman design and response surface methodology
}

\author{
Samart Sai-Ut • Soottawat Benjakul • \\ Punnanee Sumpavapol $\cdot$ Hideki Kishimura
}

Received: 2 October 2013/Accepted: 11 February 2014/Published online: 18 March 2014

(C) The Author(s) 2014. This article is published with open access at Springerlink.com

\begin{abstract}
Bacillus amyloliquefaciens $\mathrm{H} 11$ has been proven as a potential producer of extracellular protease with capacity of hydrolyzing gelatin. Therefore, the cultivation conditions for the enhanced production of gelatinolytic enzyme from a newly isolated B. amyloliquefaciens $\mathrm{H} 11$ was investigated using PlackettBurman design and response surface methodology. Three significant variables (agitation speed, cultivation time and fish gelatin concentration) were selected for optimization. Increase in speed of agitation and fish gelatin concentration markedly increased the production of gelatinolytic enzyme. Gelatin concentration and cultivation time showed significant interaction and both variables played the important role in enzyme production. The maximal gelatinolytic enzyme production in the basal medium was $2,801 \mathrm{U} / \mathrm{mL}$ under the following optimal condition: agitation speed of $234 \mathrm{rpm}, 8.36 \mathrm{~g} / \mathrm{L}$ of fish gelatin and $31 \mathrm{~h}$ of cultivation. The predicted model fitted well with the experimental results $(2,734 \pm 101 \mathrm{U} / \mathrm{mL})$. 14-fold increase in yield was achieved, compared with the basal condition $(212 \mathrm{U} / \mathrm{mL})$. Thus, cultivation of B. amyloliquefaciens $\mathrm{H} 11$ under the optimal condition could enhance the production of gelatinolytic enzyme effectively.
\end{abstract}

Keywords Bacillus amyloliquefaciens - Gelatinolytic enzyme · Optimization · Plackett-Burman design · Response surface methodology

$\begin{array}{ll}\text { Abbreviations } & \\ \text { RSM } & \text { Response surface methodological } \\ \text { TNBS } & \text { 2,4,6-Trinitrobenzenesulfonic acid } \\ \text { Tris } & \text { Tris (hydroxymethyl) aminomethane } \\ \text { U } & \text { Unit } \\ \text { NB } & \text { Nutrient broth }\end{array}$

S. Sai-Ut $(\bowtie) \cdot$ S. Benjakul · P. Sumpavapol

Department of Food Technology, Faculty of Agro-Industry, Prince of Songkla University, Hat Yai, Songkhla 90112,

Thailand

e-mail: samart_atom@yahoo.com

S. Benjakul

e-mail: soottawat.b@psu.ac.th

P. Sumpavapol

e-mail: punnanee.s@psu.ac.th

H. Kishimura

Department of Marine Bioresources Chemistry, Graduate School of Fisheries Sciences, Hokkaido University, Hakodate,

Hokkaido 041-8611, Japan

e-mail: kishi@ fish.hokudai.ac.jp 


$\begin{array}{ll}\mathrm{A}_{600} & \text { Absorbance at } 600 \mathrm{~nm} \\ \alpha \text { amino acid } & \text { Alpha amino acid } \\ \mathrm{DF} & \text { Degree of freedom } \\ \mathrm{SS} & \text { Sum of squares } \\ \text { MS } & \text { Mean square } \\ R^{2} & \text { r squared }\end{array}$

\section{Introduction}

Proteases are important enzymes, accounting for $>65 \%$ of the total worldwide enzyme sales (Oskouie et al. 2008). Proteases have been used for various industrial applications, e.g. dairy, food, pharmaceutical, leather, wool and detergent industries (Johnvesly and Naik 2001). Microbial proteases, especially from Bacillus sp., have traditionally held the predominant share of industrial enzyme market (Gupta et al. 2002a, b) since they possess almost all characteristics desired for biotechnological applications.

Generally, microbial proteases have been produced by fermentation under controlled conditions. It is well known that extracellular protease production by microorganisms is greatly influenced by the medium compositions, especially carbon and nitrogen sources. Other factors such as temperature, $\mathrm{pH}$, incubation time, agitation and inoculum density also play a role in protease production (Johnvesly and Naik 2001). Approximately $30-40 \%$ of the production cost for industrial enzyme is due to the media. Hence, optimization of medium composition is vital (Kirk et al. 2002). Optimization of medium compositions by the traditional "onefactor-at-a-time" strategy is the most frequently used process in biotechnology (Haaland 1989). However, this strategy is extremely time-consuming and expensive when a large number of variables need to be considered. In addition, this method is unable to detect true optimal conditions as a result of the interactions among different production factors.

Several statistical approaches involving Plackett-Burman designs and response surface methodology (RSM) have created a potential for optimization of enzyme production (Reddy et al. 2008). The PlackettBurman design has been used for the screening of the main factors from a large number of variables, and this information can be retained in further optimization (Haddar et al. 2010). RSM is a collection of statistical techniques that is useful for designing experiments, building models, evaluating the effects of different factors and searching for optimal conditions of studied factors for desirable responses (Haddar et al. 2010).

Collagen- and gelatin-derived peptides have gained increasing interest as the functional foods or drink as well as healthcare products (Watanabe 2004). Gelatin hydrolysate can be prepared by several commercial proteases. To enhance the hydrolysis toward gelatin, gelatinolytic proteases, which preferably hydrolyze gelatin, should be used to gain the peptides with enhanced bioactivity (Watanabe, 2004). Most of gelatinolytic enzymes are metalloprotease, capable of hydrolyzing the peptide bonds between Y and Gly-X of collagen and gelatin structure (repeated Gly-X-Y unit) (Watanabe, 2004). Gelatinolytic proteases are produced by several bacteria such as Clostridium histolyticum (Matsushita et al. 1999), Geobacillus collagenovorans (Okamoto et al. 2001) and Alicyclobacillus sendaiensis strain NTAP-1 (Tsuruoka et al. 2003). Bacillus amyloliquefaciens $\mathrm{H} 11$ has been recently identified as a potential producer of extracellular serine-metallo proteases, which effectively hydrolysed gelatin (Sai-Ut et al. 2013). The production of enzyme by this strain can be optimized to obtain the higher yield with lower production cost. Nevertheless, cultivation conditions determining the production of gelatinolytic enzyme by this strain have not been studied. Thus, this investigation aimed to implement the statistical approaches for optimization of culture conditions to maximize the production of gelatinolytic enzyme from B. amyloliquefaciens H11.

\section{Materials and methods}

Chemicals and media

2,4,6-Trinitrobenzenesulfonic acid (TNBS) was purchased from Sigma-Aldrich Canada Ltd. (Oakville, ON, Canada). Tris (hydroxymethyl) aminomethane (Tris), and calcium chloride $\left(\mathrm{CaCl}_{2}\right)$ were obtained from Merck 
(Darmstadt, Germany). Fish skin gelatin with bloom strength of 230-250 g was purchased from Lapi Gelatine S.p.A. (Milano, Italy). Peptone and nutrient broths were produced from HiMedia Laboratory (Mumbai, India). Other chemicals were of analytical grade.

Microorganism and culture maintenance

The microorganism with gelatinolytic activity used in this study was isolated from fish dock (Sai-Ut et al. 2013). It was identified as B. amyloliquefaciens $\mathrm{H} 11$ by $16 \mathrm{~S}$ rRNA gene sequencing. A bacterium was kept frozen at $-40{ }^{\circ} \mathrm{C}$ in nutrient broth [digest of animal tissue $(5 \mathrm{~g} / \mathrm{L}), \mathrm{NaCl}(5 \mathrm{~g} / \mathrm{L})$, beef extract $(1.5 \mathrm{~g} / \mathrm{L})$, and yeast extract $(1.5 \mathrm{~g} / \mathrm{L})(\mathrm{NB})]$ supplemented with $20 \%(\mathrm{v} / \mathrm{v})$ glycerol. The bacterium was sub-cultured twice in $\mathrm{NB}$ at $37{ }^{\circ} \mathrm{C}$ for $24 \mathrm{~h}$ before use as inoculums.

Inoculum preparation and gelatinolytic enzyme production

Seed culture was prepared by transferring $0.5 \mathrm{~mL}$ of inoculum $\left(A_{600 \mathrm{~nm}}=2.00\right)$ into a 250 -mL Erlenmeyer flask containing $50 \mathrm{~mL}$ of nutrient broth (NB). The cultures were grown at $37{ }^{\circ} \mathrm{C}$ with continuous shaking at $150 \mathrm{rpm}$ for $18 \mathrm{~h}$ to obtain a seed culture with an absorbance at $600 \mathrm{~nm}\left(A_{600}\right)$ of 2.0 .

To produce gelatinolytic enzyme, seed culture was inoculated into a 500-mL Erlenmeyer flask containing $150 \mathrm{~mL}$ of production medium. The compositions of production medium and growth conditions were designated as per experimental design (Tables 1,2$)$. Peptone broth $(5 \mathrm{~g} / \mathrm{L})$ was used as the basal medium for preliminary study of gelatinolytic enzyme production. After cultivation, the cells were removed by

Table 1 Experimental variable at different levels, estimated effect, regression coefficient and corresponding $t$ and $P$ values for gelatinolytic enzyme production by B. amyloliquefaciens H11 in seven variable Plackett-Burman design experiments

\begin{tabular}{|c|c|c|c|c|c|c|c|}
\hline \multirow[t]{2}{*}{ No. } & \multirow[t]{2}{*}{ Variables } & \multicolumn{2}{|l|}{ Levels } & \multirow[t]{2}{*}{ Estimate } & \multirow[t]{2}{*}{ Coefficient } & \multirow[t]{2}{*}{$t$ value } & \multirow[t]{2}{*}{$P$ value } \\
\hline & & -1 level & +1 level & & & & \\
\hline$X_{1}$ & Peptone $(\mathrm{g} / \mathrm{L})$ & 1 & 5 & -123.7 & -61.8 & -1.61 & 0.184 \\
\hline$X_{2}$ & Gelatin $(\mathrm{g} / \mathrm{L})$ & 5 & 10 & 373.3 & 186.6 & 4.85 & 0.008 \\
\hline$X_{3}$ & Initial $\mathrm{pH}$ & 7 & 9 & 136.5 & 68.2 & 1.77 & 0.151 \\
\hline$X_{4}$ & Inoculum size $(\%, \mathrm{v} / \mathrm{v})$ & 1 & 5 & -181.6 & -90.8 & -2.36 & 0.078 \\
\hline$X_{5}$ & Cultivation temperature $\left({ }^{\circ} \mathrm{C}\right)$ & 30 & 40 & -227.8 & -113.9 & -2.96 & 0.042 \\
\hline$X_{6}$ & Cultivation time $(\mathrm{h})$ & 24 & 48 & 490.2 & 245.1 & 6.37 & 0.003 \\
\hline$X_{7}$ & Agitation speed (rpm) & 0 & 200 & 589.7 & 294.9 & 7.66 & 0.002 \\
\hline
\end{tabular}

Table 2 Plackett-Burman design for screening important variables for gelatinolytic enzyme production by B. amyloliquefaciens H11

\begin{tabular}{llrllllrc}
\hline Runs & $X_{1}$ & $X_{2}$ & $X_{3}$ & $X_{4}$ & $X_{5}$ & $X_{6}$ & $X_{7}$ & $\mathrm{U} / \mathrm{mL}$ \\
\hline 5 & 5 & 10 & 7 & 5 & 40 & 24 & 200 & $617.32 \pm 53.48$ \\
1 & 1 & 10 & 9 & 1 & 30 & 24 & 200 & $810.29 \pm 122.31$ \\
12 & 1 & 5 & 7 & 1 & 30 & 24 & 0 & $214.12 \pm 46.26$ \\
8 & 1 & 5 & 9 & 5 & 40 & 24 & 200 & $563.45 \pm 42.79$ \\
4 & 1 & 10 & 9 & 5 & 30 & 48 & 0 & $437.12 \pm 214.06$ \\
9 & 1 & 5 & 7 & 5 & 40 & 48 & 0 & $288.70 \pm 82.46$ \\
3 & 5 & 5 & 9 & 1 & 40 & 24 & 0 & $313.87 \pm 59.10$ \\
7 & 5 & 5 & 9 & 5 & 30 & 48 & 200 & $1,538.48 \pm 302.75$ \\
2 & 5 & 10 & 7 & 5 & 30 & 24 & 0 & $230.85 \pm 36.77$ \\
10 & 1 & 10 & 7 & 1 & 40 & 48 & 200 & $787.16 \pm 138.83$ \\
6 & 5 & 10 & 9 & 1 & 40 & 48 & 0 & $966.80 \pm 269.90$ \\
11 & 5 & 5 & 7 & 1 & 30 & 48 & 200 & $1,673.04 \pm 308.56$ \\
\hline
\end{tabular}


centrifugation at $10,000 \times g$ and at $4{ }^{\circ} \mathrm{C}$ for 10 min using Allegra ${ }^{\mathrm{TM}} 25 \mathrm{R}$ centrifuge (Beckman Coulter, Palo Alto, CA, USA). The cell-free supernatant was analyzed for gelatinolytic activity.

Assay for gelatinolytic activity

To measure gelatinolytic activity, the supernatant was assayed using fish gelatin as a substrate as per the method of McLaughlin and Weiss (1996). A reaction mixture was $50 \mathrm{mM}$ Tris- $\mathrm{HCl}$ (pH 7.5) containing $0.36 \mathrm{mM} \mathrm{CaCl}_{2}$, and $5 \mathrm{mg} / \mathrm{mL}$ of fish gelatin. Reaction mixture was incubated at $37{ }^{\circ} \mathrm{C}$ for $30 \mathrm{~min}$. To initiate reaction, $0.1 \mathrm{~mL}$ of supernatant was added. Reaction was stopped by submerging the reaction mixture in water bath at $90{ }^{\circ} \mathrm{C}$ for $10 \mathrm{~min}$ (Memmert, Schwabach, Germany). The $\alpha$-amino acid content in the mixture was determined according to the method of Benjakul and Morrissey (1997). To diluted samples (125 $\mu \mathrm{L}), 2.0 \mathrm{ml}$ of $0.20 \mathrm{M}$ phosphate buffer, $\mathrm{pH} 8.2$ and $1.0 \mathrm{~mL}$ of $0.01 \%$ (v/v) TNBS solution were added. The solution was mixed thoroughly and placed in a temperature-controlled water bath at $50{ }^{\circ} \mathrm{C}$ for $15 \mathrm{~min}$ in the dark. The reaction was terminated by adding $2.0 \mathrm{~mL}$ of $0.1 \mathrm{M}$ sodium sulfite. The mixtures were cooled at room temperature for $15 \mathrm{~min}$. The absorbance was read at $420 \mathrm{~nm}$ and $\alpha$-amino acid content was expressed in terms of L-leucine. One unit (U) of gelatinolytic activity was defined as the amount of enzyme which released $1 \mu \mathrm{mol}$ of $\alpha$-amino acid per min under the specified condition.

Selection of significant variables by Plackett-Burman design

Impact of several variables including nitrogen sources and cultivation parameters was studied using the Plackett-Burman design for 12 runs and 7 two-level factors. The Minitab v.15 statistical package (Minitab Inc., State College, PA, USA) was used to analyze the data. Based on the Plackett-Burman factorial design, two levels were tested for each factor: -1 for a low level and +1 for a high level (Table 1$)$. The variables were as follows: (1) peptone concentration, (2) fish gelatin concentration, (3) initial $\mathrm{pH}$, (4) inoculum size, (5) cultivation temperature, (6) cultivation time and (7) speed of agitation. The experimental design with the name, symbol code, and actual level of the variables is shown in Table 2. The principal effects of each variable on gelatinolytic activity were estimated as the difference between averages of measurements made at the higher level and at the lower level.

Effect of cultivation temperature on gelatinolytic enzyme production

To study the effect of the cultivation temperature on the production of gelatinolytic enzyme, $500 \mu \mathrm{L}$ inoculum of culture was transferred into $50 \mathrm{~mL}$ of the basal media $(5 \mathrm{~g} / \mathrm{L}$ peptone) containing $5 \mathrm{~g} / \mathrm{L}$ fish gelatin $\mathrm{pH}, 7.4$ and incubated at $30,32.5,35,37.5$ and $40{ }^{\circ} \mathrm{C}$ for 24 and $48 \mathrm{~h}$. After cell removal by centrifugation $\left(10,000 \times g\right.$ and at $4{ }^{\circ} \mathrm{C}$ for $\left.10 \mathrm{~min}\right)$, gelatinolytic activity of cell-free supernatant was determined as previously described. The gelatinolytic activity at different temperatures was reported, relative to the highest activity obtained.

Optimization by response surface methodology

Response surface methodology (RSM), using a central composite design (CCD), was adopted for further optimization of gelatinolytic enzyme production. The significant variables studied included fish gelatin concentration cultivation time and speed of agitation, in which each was assessed at five coded levels (Table 3). A total of 20 experiments were conducted. The central values of all variables were coded as zero. The minimum and maximum ranges of the variables were used, and the full experimental plan with regard to their values in actual and coded form was provided in Table 4. The response values $(Y)$ in each trial were the average of the triplicates. The experimental data were fitted to a second-order polynomial model and the regression coefficients were obtained by multiple linear regression.

$$
Y=\beta_{0}+\sum_{i=1}^{3} \beta_{i} X_{i}+\sum_{i=1}^{3} \beta_{i i} X_{i}^{2}+\sum_{i=1}^{3} \sum_{j=2}^{3} \beta_{i j} X_{i} X_{j}
$$


Table 3 Independent variables and their coded and actual values used for optimization of gelatinolytic enzyme production by $B$. amyloliquefaciens $\mathrm{H} 11$

\begin{tabular}{|c|c|c|c|c|c|c|c|}
\hline \multirow[t]{2}{*}{ Independents variables } & \multirow[t]{2}{*}{ Units } & \multirow[t]{2}{*}{ Symbol } & \multicolumn{5}{|c|}{ Code levels } \\
\hline & & & $-\alpha$ & -1 & 0 & +1 & $+\alpha$ \\
\hline Fish gelatin concentration & $\mathrm{g} / \mathrm{L}$ & $X_{2}$ & 1.64 & 3.00 & 5.00 & 7.00 & 8.36 \\
\hline Cultivation time & $\mathrm{h}$ & $X_{6}$ & 15.8 & 24.0 & 36.0 & 48.0 & 56.2 \\
\hline Agitation speed & $\mathrm{rpm}$ & $X_{7}$ & 66 & 100 & 150 & 200 & 234 \\
\hline
\end{tabular}

Table 4 Experimental designs used in RSM studies using three independent variables, observed and predicted values of gelatinolytic enzyme production by $B$. amyloliquefaciens $\mathrm{H} 11$

\begin{tabular}{|c|c|c|c|c|c|}
\hline \multirow[t]{2}{*}{ Trials } & \multirow[t]{2}{*}{$X_{2}$} & \multirow[t]{2}{*}{$X_{6}$} & \multirow[t]{2}{*}{$X_{7}$} & \multicolumn{2}{|c|}{ Gelatinolytic activity $(\mathrm{U} / \mathrm{mL})$} \\
\hline & & & & Observed $^{\mathrm{a}}$ & Predicted \\
\hline 1 & 3.00 & 24.0 & 100 & $1,136 \pm 142$ & 1,023 \\
\hline 2 & 3.00 & 24.0 & 200 & $1,843 \pm 177$ & 1,881 \\
\hline 3 & 3.00 & 48.0 & 100 & $600 \pm 129$ & 638 \\
\hline 4 & 3.00 & 48.0 & 200 & $1,148 \pm 150$ & 1,179 \\
\hline 5 & 7.00 & 24.0 & 100 & $1,994 \pm 145$ & 1,905 \\
\hline 6 & 7.00 & 24.0 & 200 & $2,568 \pm 111$ & 2,472 \\
\hline 7 & 7.00 & 48.0 & 100 & $2,127 \pm 46$ & 2,031 \\
\hline 8 & 7.00 & 48.0 & 200 & $2,225 \pm 61$ & 2,280 \\
\hline 9 & 5.00 & 36.0 & 66 & $1,247 \pm 139$ & 1,373 \\
\hline 10 & 5.00 & 36.0 & 234 & $2,350 \pm 106$ & 2,304 \\
\hline 11 & 5.00 & 15.8 & 150 & $1,669 \pm 53$ & 1,795 \\
\hline 12 & 5.00 & 56.2 & 150 & $1,357 \pm 23$ & 1,311 \\
\hline 13 & 1.64 & 36.0 & 150 & $851 \pm 123$ & 825 \\
\hline 14 & 8.36 & 36.0 & 150 & $2,388 \pm 145$ & 2,493 \\
\hline 15 & 5.00 & 36.0 & 150 & $1,823 \pm 93$ & 1,802 \\
\hline 16 & 5.00 & 36.0 & 150 & $1,887 \pm 81$ & 1,802 \\
\hline 17 & 5.00 & 36.0 & 150 & $1,744 \pm 67$ & 1,802 \\
\hline 18 & 5.00 & 36.0 & 150 & $1,858 \pm 97$ & 1,802 \\
\hline 19 & 5.00 & 36.0 & 150 & $1,808 \pm 166$ & 1,802 \\
\hline 20 & 5.00 & 36.0 & 150 & $1,705 \pm 60$ & 1,802 \\
\hline
\end{tabular}

a The observed values of gelatinolytic activity were the mean values of triplicates

where $Y$ is the predicted response (gelatinolytic activity), $X_{i}$ and $X_{j}$ the coded forms of the input variables, $\beta_{0}$ is the model constant, $\beta_{i}$ is the linear coefficient, $\beta_{i i}$ is the quadratic coefficient and $\beta_{i j}$ is the interaction coefficient.

The fitted polynomial equation was then expressed in the form of three-dimensional surface plots, in order to illustrate the relationship between gelatinolytic enzyme production and the experimental variables used. The response surface plots were developed using the Statistica Kernel Release 7.0.61.0 EN (StatSoft Inc., Tulsa, OK, USA) for Windows. The point optimization method was employed in order to optimize the level of each variable for maximum response. The combination of different optimized variables, which yielded the maximum response, was used to produce the gelatinolytic enzyme to verify the validity of model. The Minitab v.15 statistical package was used for the experimental design.

\section{Results and discussion}

Screening of significant variables using Plackett-Burman design

Seven variables were analyzed for their impact on the production of gelatinolytic enzyme by $B$. amyloliquefaciens sp. H11 using a Plackett-Burman design (Table 1). The design matrix for the screening of 
significant variables for enzyme production and the corresponding responses are shown in Table 2 . The adequacy of the model was calculated, and the variables exhibiting statistically significant effects were screened using the Student's $t$ test for ANOVA (Table 1). Factors with $P$ value lower than 0.05 were considered to have significant effects on the production of gelatinolytic enzyme, and were therefore selected for further optimization studies. Speed of agitation, with a $P$ value of 0.002 , was considered as the most significant factor, followed by cultivation time (0.003), fish gelatin concentration (0.008), and cultivation temperature (0.042), respectively. Among all significant variables, the cultivation temperature exerted a negative effect ( $t$ value of -2.96), whereas other variables showed the positive effects on gelatinolytic enzyme production. Plackett-Burman design experiments on production of gelatinolytic enzyme from $B$. amyloliquefaciens sp. H11 indicated that the most important parameters were speed of agitation, fish gelatin concentration and cultivation time. Oxygen is a universal component of cells. However, prokaryotes display a wide range of responses to molecular oxygen (Dworkin et al. 2006). In the presence of gelatin, B. amyloliquefaciens $\mathrm{H} 11$ produced gelatinolytic enzyme to a higher extent, plausibly due to their catabolite repression, allowing bacteria to synthesize more gelatinolytic enzyme (Deutscher 2008). Liu et al. (2010) reported that initial $\mathrm{pH}$, glycerol, and $\mathrm{MgSO}_{4} \cdot 7 \mathrm{H}_{2} \mathrm{O}$ were the most significant variables affecting protease productivity from B. sphaericus DS11. Pillai et al. (2011) showed that soya bean meal and minerals $\left(\mathrm{BaCl}_{2}, \mathrm{KH}_{2} \mathrm{PO}_{4}, \mathrm{CaCl}_{2}\right)$ had an enhancing effect on protease production by $B$. subtilis P13.

Hence, those three factors were considered as the independent variables and their effects on gelatinolytic enzyme production were further studied using a central composite design (CCD) of RSM. For non-significant variables, their fixed conditions for RSM [5 g/L peptone, $\mathrm{pH} 8$, and $1 \%$ (v/v) inoculum size] were used. Most of culture media containing $5 \mathrm{~g} / \mathrm{L}$ peptone with $\mathrm{pH} 8$ have been used for culturing Bacillus sp. (Montville and Schaffner 2003).

Effect of the cultivation temperature

Effect of different cultivation temperatures on the production of gelatinolytic enzyme was determined as shown in Fig. 1. Cultivation condition included $1 \%(\mathrm{v} / \mathrm{v})$ inoculum in basal medium $(5 \mathrm{~g} / \mathrm{L}$ peptone $\mathrm{pH} 7.4)$ containing $5 \mathrm{~g} / \mathrm{L}$ fish gelatin for 24 and $48 \mathrm{~h}$. The highest gelatinolytic activity was obtained at $37.5{ }^{\circ} \mathrm{C}$ $(P<0.05)$ for both cultivation times. The result suggested that an optimum temperature of $37.5^{\circ} \mathrm{C}$ might promote cell growth as well as enzyme synthesis. At higher temperature $\left(40{ }^{\circ} \mathrm{C}\right)$, the decrease in activity was observed, especially for $48 \mathrm{~h}$. This might be associated with the lower cell growth at this temperature, thereby decreasing enzyme production. Temperature dependence of protein synthesis of microbial cells may be related with the changes in transportation of amino acids and the alteration of soluble components involved in protein synthesis (Raki 1991). It has been reported that most of Bacillus strains were of mesophilic type with optimal temperature of $30-37^{\circ} \mathrm{C}$. Our finding was in accordance with several earlier reports for Bacillus sp., B. brevis

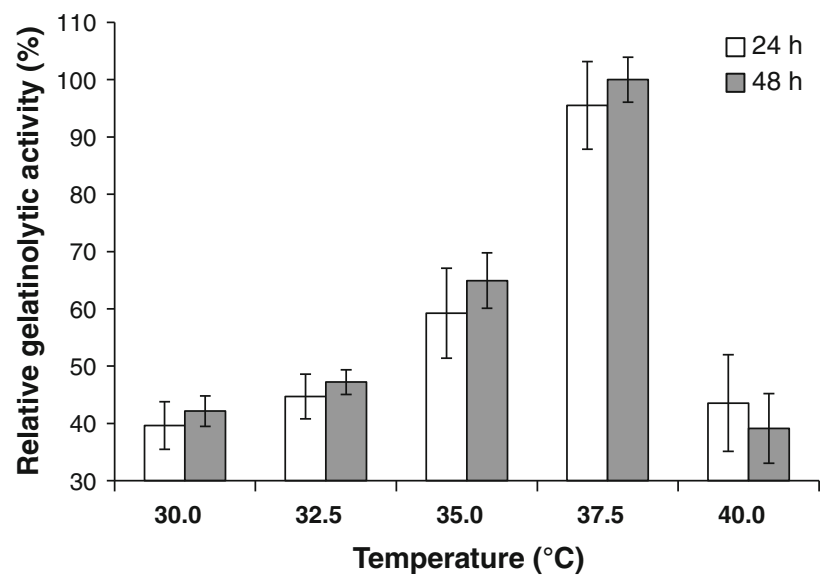

Fig. 1 Effect of cultivation temperatures on gelatinolytic enzyme production by B. amyloliquefaciens H11 (1\%, v/v inoculum in the basal medium containing $5 \mathrm{~g} / \mathrm{L}$ fish gelatin). Activity was expressed, relative to the highest gelatinolytic activity obtained at $37.5^{\circ} \mathrm{C}$ for 24 and 48 h. Bars represented the standard deviation $(n=3)$ 
(Banerjee et al. 1999), Bacillus sp. strain CA15 (Uyar et al. 2011), B. licheniformis ATCC 21415 (Mabrouk et al. 1999), Bacillus sp. TSG437 (Puri et al. 2002), and Bacillus strains I18, L18 and L21 (Genckal and Tari 2006). Thus, cultivation temperature of $37.5^{\circ} \mathrm{C}$ was used for optimization of gelatinolytic enzyme production using RSM.

Optimization of significant variables using response surface methodology

Based on CCD experiment, the effects of three independent variables including speed of agitation, fish gelatin concentration and cultivation time on gelatinolytic enzyme production are shown in Table 4. The predicted and observed responses were reported. The results obtained from CCD were then analyzed by standard analysis of variance (ANOVA), and the quadratic regression equation was applied for prediction of gelatinolytic enzyme production (Table 5). Based on the full quadratic model application, it appeared that the speed of agitation $\times$ cultivation time $(P$ value $=0.065)$ and speed of agitation $\times$ fish gelatin concentration $(P$ value $=0.086)$ interaction as well as quadratic effect for speed of agitation $(P$ value $=0.659)$ and fish gelatin concentration $(P$ value $=0.108)$ could be eliminated from the model because the coefficient for interaction was not different from $0\left(H_{0}: \beta_{\mathrm{i}}=0\right)$. Even though the speed of agitation showed no interaction with fish gelatin concentration and cultivation time, the linear effect for speed of agitation was still considered as an important factor in this model $(P<0.05)$. After using the designed experimental data and eliminating some terms, the polynomial model for gelatinolytic enzyme produced $(Y)$ was regressed by only considering the significant terms $(P<0.05)$ as shown in the following equation:

$$
Y=1802.01+495.87 X_{2}-143.95 X_{6}+276.91 X_{7}+127.52 X_{2} X_{6}
$$

where $Y$ is the predicted gelatinolytic enzyme yield, $X_{2}$ is fish gelatin concentration, $X_{6}$ is cultivation time, and $X_{7}$ is speed of agitation.

For interaction of those variables, there was the interaction only between gelatin concentration and cultivation time $(P<0.05)$. This interaction was constructed by plotting both variables together (data not shown). The interaction of gelatin concentration and cultivation time indicated the importance of those factors for gelatinolytic enzyme production. The maximum gelatinolytic enzyme production was achieved $(\sim 2,800 \mathrm{U} /$ $\mathrm{mL})$ at the high gelatin concentration $(\sim 8 \mathrm{~g} / \mathrm{L})$ with the cultivation time of $30-32 \mathrm{~h}$. The increasing gelatin concentration caused a slight shift of cultivation time to higher value, in which gelatinolytic enzyme production increased. The result suggested that higher gelatin concentration might provide the sufficient nutrient for bacteria to produce enzyme and this might be associated with a slightly extended cultivation time.

The regression equation obtained from analysis of variance (ANOVA) with the $R^{2}$ value (multiple correlation coefficients) of 0.9773 revealed that the model could explain $97.73 \%$ variation in the response. The "adjusted $R^{2}$ " and "predicted $R^{2}$ " values were 0.9569 and 0.8521 , respectively. $R^{2}$ values were close to 1.0 and all three factors were positive and close to each other, indicating the good statistical model (Myers et al.

Table 5 Analysis of variance (ANOVA) for the parameters of response surface methodology fitted to second-order polynomial equation for gelatinolytic enzyme production by $B$. amyloliquefaciens $\mathrm{H} 11$

\begin{tabular}{|c|c|c|c|c|c|}
\hline Source of variation & $D F$ & SS & MS & $t$ value & $P$ value \\
\hline Regression & 9 & $5,057,587$ & 561,954 & 47.92 & 0.000 \\
\hline Linear & 3 & $4,688,269$ & $1,562,756$ & 133.25 & 0.000 \\
\hline Square & 3 & 146,233 & 48,744 & 4.16 & 0.037 \\
\hline Interaction & 3 & 223,085 & 74,362 & 6.34 & 0.011 \\
\hline Residual error & 10 & 117,276 & 11,728 & & \\
\hline Lack of fit & 5 & 93,814 & 18,763 & 4.00 & 0.077 \\
\hline Pure error & 5 & 23,462 & 4,692 & & \\
\hline Total & 19 & $5,174,863$ & & & \\
\hline
\end{tabular}

$R^{2}, 0.9773$; Adj- $R^{2}, 0.9569 ;$ Pred- $R^{2}, 0.8521$

$D F$ degree of freedom, $S S$ sum of squares, $M S$ mean square 


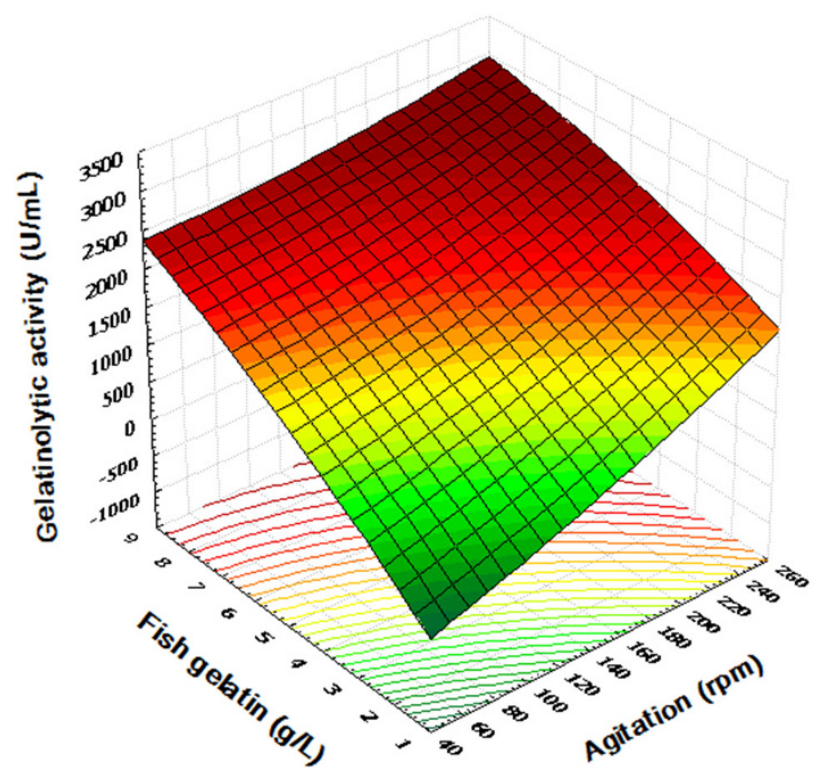

Fig. 2 Response surface plots for gelatinolytic enzyme production by B. amyloliquefaciens H11. The interaction between fish gelatin concentration and agitation speed

2004). The $P$ values of the model $(<0.0001)$ and non-significant lack of fit $(0.077)$ also suggested that the obtained experimental data showed a good fit with the model. ANOVA analysis also confirmed a satisfactory adjustment of the reduced quadratic model to the experimental data.

The three-dimensional response surface graphs were plotted to illustrate the interaction of the cultivation parameters and the optimum level of tested components on gelatinolytic activity. From the contour plots, general quadratic surface types of all response surface plots were response surface rising ridge. The relationship between cultivation time and agitation speed was curvilinear to nearly linear when moving from the lower to the higher level (data not shown). This was similar to the relationship between cultivation time and agitation speed (Fig. 2). It was noted that the relationship between fish gelatin concentration and cultivation time was curvilinear in a large portion of the middle levels. An increase in agitation speed tended to increase gelatinolytic activity, more likely due to higher oxygen supply and nutrient transfer rate. At higher speed, cell growth could be more promoted (Genckal and Tari 2006), thereby producing more enzyme. It was obvious from the given data that the strain required high agitation speed for enzyme synthesis, probably due to the requirement for oxygen. The present results supported the previous findings (Gupta et al. 2002a, b; Joo et al. 2002; Joo and Chang 2005; Reddy et al. 2008; Rai and Mukherjee 2010; Liu et al. 2010).

The response varied as a function of fish gelatin concentration showed a response surface rising ridge (data not shown). The model predicted the increase in gelatinolytic activity with increasing fish gelatin concentration. These results clearly indicated that fish gelatin was a major factor influencing gelatinolytic enzyme production by $B$. amyloliquefaciens $\mathrm{H} 11$. Due to limitation of agitation speed and gel formation of fish gelatin at high concentration (greater than $10 \mathrm{~g} / \mathrm{L}$ ), the factor levels located on the top of the ridge (speed of $234 \mathrm{rpm}$ and concentration of $8.36 \mathrm{~g} / \mathrm{L}$ fish gelatin) were selected. As shown in Fig. 2, it was apparent that gelatinolytic enzyme production increased steadily when speed of agitation and fish gelatin concentration increased. With increasing cultivation time, gelatinolytic enzyme production increased and reached the plateau at some period of time. Thereafter, no appreciable change in gelatinolytic activity was observed, even with longer cultivation time (Fig. 2). The decrease in gelatinolytic activity with the extended cultivation time could be because of autolysis of enzymes. A broad cultivation time ranging from 24 to $120 \mathrm{~h}$ was used for production of protease by Bacillus strains (Mabrouk et al. 1999; Beg and Gupta 2003; Chu et al. 1992). Maximal protease production within 16-92 h was reported for B. horikoshii (Joo et al. 2002), B. licheniformis NCIM-2042 (Potumarthi et al. 2007), and Bacillus sp. RGR-14 (Chauhan and Gupta 2004), respectively. 
Thus, the optimum conditions for gelatinolytic enzyme production with the real practice were proposed with the following condition: speed of agitations at $234 \mathrm{rpm}, 8.36 \mathrm{~g} / \mathrm{L}$ of fish gelatin and $31.7 \mathrm{~h}$ of cultivation time. The maximal gelatinolytic activity of $2,801 \mathrm{U} / \mathrm{mL}$ was predicted by the model.

Validation of the experimental model

The validation of the statistical model and regression equation was conducted by cultivation $B$. amyloliquefaciens $\mathrm{H} 11$ in the basal medium containing $8.36 \mathrm{~g} / \mathrm{L}$ fish gelatin by shaking at $234 \mathrm{rpm}$ for $31.7 \mathrm{~h}$. Under this optimized condition, the observed experimental value was $2,734 \pm 101 \mathrm{U} / \mathrm{mL}$. The close relationship between the predicted $(2,801 \mathrm{U} / \mathrm{mL})$ and experimental response value from the validation experiment revealed the validity and acceptability of the statistical model for the optimization of the agitation speed, cultivation time and fish gelatin concentration. Therefore, the effective economization of gelatinolytic enzyme production by B. amyloliquefaciens H11 could be achieved and further implemented for larger-scale production.

\section{Conclusions}

The optimization of gelatinolytic enzyme production by B. amyloliquefaciens $\mathrm{H} 11$ was achieved by statistical models and experimental design. Speed of agitation and fish gelatin concentration had the strong influence in gelatinolytic enzyme production. The optimal condition for maximal gelatinolytic enzyme production was cultivation of $B$. amyloliquefaciens $\mathrm{H} 11$ in the basal medium containing $8.36 \mathrm{~g} / \mathrm{L}$ fish gelatin with continuous shaking at $234 \mathrm{rpm}$ for $31 \mathrm{~h}$ at $37.5^{\circ} \mathrm{C}$.

Acknowledgments The authors wish to thank National Research University Project of Thailand's Office of the Higher Education Commission, the TRF Senior Research Scholar Program and Graduate School, Prince of Songkla University for funding this project.

Conflict of interest The authors declare that they have no competing interests.

Authors' contributions SB developed the initial idea and designed the study. SS was responsible for conducting experiments and analysis of data. PS and SS carried out the analytical work. SS wrote the manuscript with assistance from SB. SB and HK read and approved the final manuscript.

Open Access This article is distributed under the terms of the Creative Commons Attribution License which permits any use, distribution, and reproduction in any medium, provided the original author(s) and the source are credited.

\section{References}

Banerjee CU, Sani RK, Azmi W, Soni R (1999) Thermostable alkaline protease from Bacillus brevis and its characterization as a laundry detergent additive. Process Biochem 35:213-219

Beg QK, Gupta R (2003) Purification and characterization of an oxidation stable, thiol-dependent serine alkaline protease from Bacillus mojavensis. Enzyme Microb Technol 32:294-304

Benjakul S, Morrissey MT (1997) Protein hydrolysates from Pacific whiting solid waste. J Agric Food Chem 45:3423-3430

Chauhan B, Gupta R (2004) Application of statistical experimental design for optimization of alkaline protease production from Bacillus sp. RGR-14. Process Biochem 39:2115-2122

Chu IM, Lee C, Li TS (1992) Production and degradation of alkaline protease in batch cultures of Bacillus subtilis ATCC 14416. Enzyme Microb Technol 14:755-761

Deutscher J (2008) The mechanisms of carbon catabolite repression in bacteria. Curr Opin Microbiol 11(2):87-93

Dworkin M, Falkow S, Rosenberg E, Schleifer KH, Stackebrandt E (2006) The Prokaryotes. In: Ecophysiology and Biochemistry, vol 2. Springer, New York, p 124

Genckal H, Tari C (2006) Alkaline protease production from alkalophilic Bacillus sp. isolated from natural habitats. Enzyme Microb Technol 39:703-710

Gupta R, Beg QK, Khan S, Chauhan B (2002a) An overview on fermentation, downstream processing and properties of microbial alkaline proteases. Appl Microb Biotechnol 60:381-395

Gupta R, Beg QK, Lorenz P (2002b) Bacterial alkaline proteases: molecular approaches and industrial applications. Appl Microb Biotechnol 59:15-32

Haaland PD (1989) Statistical problem solving. In: Haaland PD (ed) Experimental design in biotechnology. Marcel Dekker, New York, pp 1-18 
Haddar A, Fakhfakh-Zouari N, Hmidet N, Frikha F, Nasri M, Kamoun AS (2010) Low-cost fermentation medium for alkaline protease production by Bacillus mojavensis A21 using hulled grain of wheat and sardinella peptone. J Biosci Bioeng 110:288-294

Johnvesly B, Naik GR (2001) Studies on production of thermostable alkaline protease from thermophilic and alkaliphilic Bacillus sp. JB-99 in a chemically defined medium. Process Biochem 37:139-144

Joo HS, Chang CS (2005) Production of protease from a new alkalophilic Bacillus sp. I-312 grown on soybean meal: optimization and some properties. Process Biochem 40:1263-1270

Joo HS, Kumar CG, Park GC, Kim KT, Paik SR, Chang CS (2002) Optimization of the production of an extra cellular alkaline protease from Bacillus horikoshii. Process Biochem 38:155-159

Kirk O, Borchert TV, Fuglsang CC (2002) Industrial enzyme applications. Curr Opin Biotechnol 13:345-351

Liu S, Fang Y, Lv M, Wang S, Chen L (2010) Optimization of the production of organic solvent-stable protease by Bacillus sphaericus DS11 with response surface methodology. Bioresour Technol 101:7924-7929

Mabrouk SS, Hashem AM, El-Shayeb NMA, Ismail MS, Abdel-Fattah AF (1999) Optimization of alkaline protease productivity by Bacillus licheniformis ATCC 21415. Bioresour Technol 69:155-159

Matsushita O, Jung CM, Katayama S, Minami J, Takahashi Y, Okabe A (1999) Gene duplication and multiplicity of collagenases in Clostridium histolyticum. J Bacteriol 181:923-933

McLaughlin B, Weiss JB (1996) Endothelial-cell-stimulating angiogenesis factor (ESAF) activates progelatinase A (72 kDa type IV collagenase), prostromelysin 1 and procollagenase and reactivates their complexes with tissue inhibitors of metalloproteinases. Biochem J 317:739-745

Montville R, Schaffner DW (2003) Inoculum size influences bacterial cross contamination between surfaces. Appl Environ Microbiol 69(12):7188-7193

Okamoto M, Yonejima Y, Tsujimoto Y, Suzuki Y, Watanabe K (2001) A thermostable collagenolytic protease with a very large molecular mass produced by thermophilic Bacillus sp. strain MO-1. Appl Microbiol Biotechnol 57:103-108

Oskouie SFG, Tabandeh F, Yakhchali B, Eftekhar F (2008) Response surface optimization of medium composition for alkaline protease production by Bacillus clausii. Biochem Eng J 39:37-42

Pillai P, Mandge S, Archana G (2011) Statistical optimization of production and tannery applications of a keratinolytic serine protease from Bacillus subtilis P13. Process Biochem 46(5):1110-1117

Potumarthi R, Ch S, Jetty A (2007) Alkaline protease production by submerged fermentation in stirred tank reactor using Bacillus licheniformis NCIM-2042: effect of aeration and agitation regimes. Biochem Eng J 34:185-192

Puri S, Khalil O, Gupta R (2002) Optimization of alkaline protease production from Bacillus sp. by response surface methodology. Curr Microbiol 44:286-290

Rai SK, Mukherjee AK (2010) Statistical optimization of production, purification and industrial application of a laundry detergent and organic solvent-stable subtilisin-like serine protease (Alzwiprase) from Bacillus subtilis DM-04. Biochem Eng J 48:173-180

Raki T (1991) The effect of temperature shifts on protein synthesis by the psychrophilic bacterium Vibrio sp. strain ANT-300. J Gen Microbiol 137:817-826

Reddy LVA, Wee YJ, Yun JS, Ryu HW (2008) Optimization of alkaline protease production by batch culture of Bacillus sp. RKY3 through Plackett-Burman and response surface methodological approaches. Bioresour Technol 99:2242-2249

Sai-Ut S, Benjakul S, Sumpavapol P (2013) Gelatinolytic enzymes from Bacillus amyloliquefaciens isolated from fish docks: characteristics and hydrolytic activity. Food Sci Biotechnol 22(4):1015-1021

Tsuruoka N, Nakayama T, Ashida M, Hemmi H, Nakao M, Minakata H, Oyama H, Oda K, Nishino T (2003) Collagenolytic serine-carboxyl proteinase from Alicyclobacillus sendaiensis strain NTAP-1: purification, characterization, gene cloning, and heterologous expression. Appl Environ Microbiol 69:162-169

Uyar F, Porsuk I, Kizil G, Yilmaz EI (2011) Optimal conditions for production of extracellular protease from newly isolated Bacillus cereus strain CA15. EurAsian J BioSci 5:1-9

Watanabe K (2004) Collagenolytic proteases from bacteria. Appl Microbiol Biotechnol 63:520-526 